\title{
Patterns of education and supervision of the headmaster in improving discipline and teacher performance
}

\author{
Hendry Faizal ${ }^{1}$, Nur Ahyani ${ }^{2}$, Nila Kesumawati ${ }^{2}$ \\ ${ }^{1}$ Sekolah Menengah Pertama Negeri 43 Satap OKU, Indonesia \\ ${ }^{2}$ Universitas PGRI Palembang, Indonesia
}

\begin{tabular}{l} 
Article Info \\
\hline Article history: \\
Received Jul $12^{\text {th }}, 2021$ \\
Revised Aug $16^{\text {th }}, 2021$ \\
Accepted Aug $30^{\text {th }}, 2021$ \\
\hline
\end{tabular}

\section{Keyword:}

Guidance and supervision

Patterns

Principals

Work discipline

Teacher performance

\begin{abstract}
This study aims to describe the pattern of guidance and supervision of the principal in improving the discipline and performance of teachers of SMP Negeri 24 Ogan Komering Ulu. This research uses qualitative methods with a descriptive approach. Data collection techniques through observation, interviews, and documentation. The research subjects were the principal, teachers and students. The results of this study indicate that the discipline of teachers at SMP Negeri 24 Ogan Komering Ulu is in a good category, this can be seen from the majority of teachers obeying and carrying out what has become the prevailing rules and norms. Teacher performance is also in the good category as evidenced by the increasing quality of learning and the results of graduates from students who can enter public high schools, if their private schools get top ten report cards. The pattern of guidance and supervision of school principals in improving teacher discipline and performance at SMP Negeri 24 Ogan Komering Ulu is by coaching teacher performance, namely following seminars and training, supervision or supervision of performance in the form of class visits every week and once a month, disciplinary fostering of educational personnel by directly monitoring teacher attendance, providing motivation, and awarding teachers in the form of awards given at each annual event.
\end{abstract}

C 2021 The Authors. Published by IICET

This is an open access article under the CC BY-NC-SA license

(https://creativecommons.org/licenses/by-nc-sa/4.0

\section{Corresponding Author:}

Faizal, H.,

Sekolah Menengah Pertama Negeri 43 Satap OKU, Indonesia

Email: hendrifaizal@gmail.com

\section{Introduction}

Education is a system and procedures for improving the quality of one's life in all aspects of life. Education has a very strategic and important value in the formation of a nation. Basically, education is a strategic means to increase the nation's potential to be able to take part in a more global level. Education is an investment to develop individuals and communities [1].

The National Education System is implemented as a whole, comprehensive and integrated, universal in the sense that it is open to all people and applies to all regions of the country, comprehensive in the sense that it includes all channels, levels, types of education and is integrated in the sense that there is a mutual interrelation between national education and all national development. National education has a vision of the realization of the education system as a strong and authoritative social institution to empower all Indonesian 
citizens to develop into qualified human beings so that they are able and proactive to respond to changing times [2].

The essence of education is the learning process, where learning cannot be separated from the teaching and learning process. Learning is an activity where a person makes or results in a change in behavior that is in him or her in knowledge, attitudes, and skills. A longstanding view in education about the position of learning as a process of transferring information from educators as the only source of information and placing students not as dynamic individuals, but rather as passive objects so that their individual potentials cannot develop optimally [3]. Such views or practices are certainly very effective in the learning process.

Patterns are form, repetition, organization or direction [4]. In addition, a pattern can also be interpreted as a set of established elements regarding a symptom and can be used as an example in describing or describing the symptom itself.

Guidance is an effort of actions and activities carried out in an efficient manner to obtain good results. Coaching is a conscious human effort to guide and direct the personality and abilities of teachers in both formal and non-formal education [5]. The coaching pattern is an effort that is carried out continuously and continuously, consciously by the institution in order to increase discipline and teacher performance. Besides applying a good and directed coaching pattern. The principal must also supervise both individually and in groups of the teacher as the main factor in improving the quality of the school.

Supervision can be defined as a process to ensure that the goals of school organization and management are achieved. This is concerned with ways of making activities as planned. This definition indicates a very close relationship between planning and supervision [6] Control or supervising is a function in functional management that must be carried out by each leader of all units / work units for the implementation of work or employees who carry out their respective main tasks. A deviation or error occurs or not during the course of work depending on the ability and skill level of the employee. Employees / teachers who always receive direction or guidance from their superiors, tend to make fewer mistakes or deviations compared to employees / teachers who do not receive guidance [7].

The principal is a functional teacher who is given the task of leading a school where teaching and learning processes are held or a place where there is interaction between the teacher who gives lessons and students who receive lessons. With this the Principal can be said to be the leader in the education unit whose job is to carry out the management of the education unit led. [8]. A school principal has tasks that need to be professional so that the desired quality of education can be achieved, especially in professions that are assigned as leaders in an educational institution [9].

The principal has a role that greatly influences the running of the existing system in schools [10]. The principal is one of the components of education that has the most role in improving the quality of education. The principal is responsible for the implementation of education, school administration, coaching other education personnel, the utilization and maintenance of facilities and infrastructure as well as a supervisor at the school he leads.

The principal also acts as a supervisor who functions as a supervisor and an example to teachers and employees at school. One of the most important things for the principal, as a supervisor, is to understand the duties and positions of the school employees or staff they lead. Thus, the principal not only supervises employees and teachers who are carrying out activities, but he equips himself with knowledge and understanding of the duties and functions of his staff, so that supervision runs smoothly and is not confusing.

As a supervisor, the principal takes concrete steps, namely: (1). formulating plans and policies, (2). involving all teachers and school staff, (3). help and encourage all subordinates to solve the problem at hand, (4). provide an example that should be emulated by his subordinates, (5). make decisions on the basis of deliberation and consensus with all subordinates, (6). pay attention to work programs and implementation of work programs in accordance with the skills of subordinates, (7). increase the creativity and idealism of his subordinates for mutual progress, (8). conduct personal coaching and work group teachers, (9). provide moral and material assistance for the progress of teachers and all employees [11].

Teacher discipline and performance are important elements in education, apart from that it is also a determinant of the high and low quality of education. Teacher performance is carried out by the teacher in carrying out the duties of a teacher as an educator. The quality of teacher performance determines the quality of educational outcomes because the teacher is the person who most often interacts directly with students during the learning process. 
Teachers in the teaching and learning process still play an important role [12]. The success of the teacher's performance is influenced by the surrounding environment. Therefore, the surrounding environment, especially in this case the school, such as the principal who is able to motivate and empower teachers and provide guidance to create good performance and be able to play a role as a professional teacher in addition to the teacher himself who is able to improve the quality of his own work.

[13] Teachers as professionals stake their profession on the quality of their work. This confirms that quality performance will describe the professional quality of a teacher, and vice versa, performance that is below work standards illustrates the failure of teachers to respect their own profession. Therefore, it is necessary to pay attention to the guidance and development of the teaching profession as a form of commitment in making improvements to educational patterns in order to achieve the quality of education as expected. The low quality of teacher skills will have an impact on the low quality of education. Teacher performance is real behavior as an achievement displayed by a teacher to carry out the educational process at a school or educational institution.

Teacher performance can be seen and measured based on the specifications or competency criteria that each teacher must have. Regulation of the Minister of National Education of the Republic of Indonesia Number 16 of 2007 concerning Academic Qualification Standards and Teacher Competencies also explains that teacher competency standards are developed as a whole into 4 main competencies, namely (a) pedagogic competence, (b) personality competence, (c) professional competence, (d) and social competence. The four competencies that become the standard for academic qualifications and teacher competencies must be thoroughly mastered by the teacher. Teacher competence will not be realized without good work discipline from a teacher. However, in reality there are still problems in its implementation.

Discipline issues and teacher performance are important issues related to improving the quality of education. This problem is also felt by SMP Negeri 24 Ogan Komering Ulu. From the results of observations found problems including: (1). Lack of teacher discipline, this can be seen from the presence of teachers who are not on time in the learning process, (2) Some teachers only carry out their duties but have not optimally carried out their role as professional educators, (3). The low performance of teachers, this can be seen from the lesson planning that has not been made optimally, such as readiness in lesson administration, preparing syllabus / lesson plans and teaching materials, (4). The low competence of teachers, this can be seen from there are still many teachers who teach not according to their field of knowledge.

\section{Method}

This research use desciptive qualitative approach. Qualitative descriptive method is used to obtain in-depth data and describe it, a data that contains meaning. Meaning is actual data, definite data which is a value behind the visible data. Therefore, qualitative research does not emphasize generalizations, but rather emphasizes meaning. [14]. In collecting the necessary data, there is a need for data collection techniques that can be used appropriately in accordance with the problem being investigated and the research objectives, so the authors use several methods that can facilitate this research, including: 1) Observation, 2) Interviews, and 3) Documentation.

\section{Results and Discussions}

The results of this research analysis are aimed at analyzing research exposure to reveal the results of research findings that are guided by the research focus in chapter I. Based on the research exposure above, the findings that can be put forward are in relation to the pattern of guidance and supervision of school principals in improving discipline and performance teachers at SMP Negeri 24 Ogan Komering Ulu are as follows:

\section{Discipline of Teachers at SMP Negeri 24 Ogan Komering Ulu}

Discipline is a condition in which something is in an orderly, orderly state and there is no violation. The teacher as a teacher, educator, and agent of reform and community development through education has an important role in educating and fostering his students through the teaching and learning process. in school. To educate and foster students, the teacher of SMP Negeri 24 Ogan Komering Ulu must have strong discipline in carrying out their duties in order to achieve educational goals.

Discipline in the educational process is very necessary because it is not only to maintain the conditions for the learning and teaching environment to run smoothly, but also to create a strong personality for every school member. Every teacher must be disciplined in carrying out their duties at school. 
Based on the results of interviews, observations and documentation that, the discipline of the teacher tends to be good, seen from the teachers of SMP Negeri 24 Ogan Komering Ulu have implemented several aspects of discipline, based on the results of interviews, observations and documentation that, the disciplinary aspect is accuracy, doing work well and obey the rules.

\section{Teacher Performance at SMP Negeri 24 Ogan Komering Ulu}

From the results of several interviews above, it is known that the performance of teachers at SMP Negeri 24 Ogan Komering Ulu has begun to improve as evidenced by the discipline of teachers, the increase in students at SMP Negeri 24 Ogan Komering Ulu from year to year, seen from the perspective of the teacher's personality, Relationships with school members, the independent teaching and learning process seen in the learning process of teachers using creative learning methods by utilizing media from used goods, and teachers who have matched their educational background with the field being taught. The school principal is still trying to improve the performance of teachers at SMP Negeri 24 Ogan Komering Ulu by facilitating teachers in carrying out their duties, monitoring the collection of lesson plans, more disciplining teachers and optimizing the teaching and learning process of teachers so that teachers at SMP Negeri 24 Ogan Komering Ulu are more professional in carrying out its duties. It is said that the teacher's performance is good, this is in accordance with the competence of teachers according to the theory of Jamil Supentangininggrum, teachers are required to have competencies which include pedagogical competences, namely abilities related to student understanding and management of student learning, personality competencies, namely personal abilities that reflect (solid personality). School Principal Guidance and Supervision Patterns in Improving Discipline and Teacher Performance at SMP Negeri 24 Ogan Komering ulu

This study shows that the pattern of guidance and supervision of school principals in improving discipline and teacher performance at SMP Negeri 24 Ogan Komering Ulu are:

1. Fostering the discipline of educational personnel by monitoring the presence of teachers directly and for teachers who are late will be given a warning and warned beforehand, if it still recurs, a warning letter will be given one to three for teachers who are late and if they have crossed the limit up to the third time then an outgoing letter will be given.

2. Teacher performance coaching, in coaching teacher performance at SMP Negeri 24 Ogan Komering Ulu by attending seminars or training and holding seminars in schools by inviting outside lecturers as event speakers, in attending seminars and training only certain teachers are sent to attend seminars organized by the government.

3. Supervision or supervision of teacher performance that the principal has carried out direct supervision of teacher performance in the form of class visits, but this activity is carried out once a week or once a month and not all teachers are monitored for their performance for teachers who are considered good at teaching. This is actually not good for other teachers because after all a teaching staff must be monitored for their performance if it is not good it can be repaired and if it is good it can continue to be improved again.

4. The school principal has motivated teachers who are deemed needy with the hope that the teacher's performance at SMP Negeri 24 Ogan Komering Ulu will get better and this motivational activity is given to teachers almost every day.

5. In terms of giving awards to teachers at SMP Negeri 24 Ogan Komering Ulu, the principal always gives awards to teachers at annual events.

Based on the results of interviews with comparative theories according to Castetter as quoted by $\mathrm{E}$. Mulyasa, namely:

1. Fostering the discipline of educational personnel in improving teacher performance, the principal must be able to cultivate the discipline of educational personnel, especially self-discipline, in this case the principal must be able to do things, namely helping education personnel develop patterns of behavior, helping educational staff increase their standard of behavior, using the implementation of rules as a tool.

2. Supervision or supervision of teacher performance through learning activities,

3. one of the efforts to improve teacher professionalism, needs guidance from the principal through academic supervision, the quality of teacher teaching can directly or indirectly affect the quality of student learning, therefore it is necessary to provide follow-up guidance from the principal, among others through teaching 
supervision.

4. Giving motivation to improve work productivity performance needs to be considered the motivation of educational staff and other factors that influence it. The motivation given can be in the form of rewards, educational scholarships, assignments, promotion of teacher performance. Teachers will be even more active in improving their performance if there is motivation or encouragement from the school principal, this can be in the form of coaching or with encouragement of words.

5. Giving awards is very important to increase work productivity and to reduce unproductive activities, through this appreciation, educational staff are stimulated to increase positive and productive performance. The principal who understands the needs of a teacher will provide encouragement so that teachers can improve their performance, this can be by increasing salary, promotion, finance, charter, and must be adjusted to the assignment given and the teacher's performance results. (Mulyasa, 2001: 111- 141)

6. Based on the facts in the field, the researchers found that the pattern of guidance and supervision of the principal in improving the discipline and performance of teachers at SMP Negeri 24 Ogan Komering Ulu is in accordance with the above theory and the principal is still trying to improve discipline and teacher performance by updating predetermined strategies. previously effectively and efficiently.

\section{Conclusions}

Based on the results and discussion above, it can be concluded into several points as follows: 1). A teacher can be said to be disciplined if the teacher has implemented disciplinary aspects in him, 2) The performance of teachers at SMP Negeri 24 Ogan Komering Ulu is in a good category as evidenced by the increased quality of learning and the results of graduates from students who can enter public high schools and if in private schools they get top ten report cards, 3) The pattern of guidance and supervision of school principals in improving teacher discipline and performance at SMP Negeri 24 Ogan Komering Ulu by coaching teacher performance, namely attending seminars and training, supervision or supervision of performance in the form of class visits every week and once a month, educational staff disciplinary guidance by directly monitoring the presence of teachers, providing motivation, and giving awards to teachers in the form of awards given at each annual event.

\section{References}

Arifin, M. 2008. Hubungan Timbal Balik Pendidikan Agama. Jakarta: Bulan Bintang Aunurrahman. 2011. Belajar dan Pembelajaran. Bandung: Alfabeta

Barnawi dan Arifin, M. 2012. Etika dan Profesi Kependidikan. Jogjakarta: Ar-ruzz. Media.

Daulay, H.P. 2009. Dinamika Pendidikan Islam di Asia Tenggara. Jakarta: Asdi Mahasatya

Hadiyanto. 2004. Mencari Sosok Desentralisasi Manajemen Pendidikan di Indonesia. Jakarta: Rineka Cipta

Herabudin. 2009. Administrasi dan Supervisi Pendidikan. Bandung : Pustaka Setia

Kadarisman, M. 2013. Manajemen Pengembangan Sumber Daya Manusia. Jakarta: Rajawali

Kristiawan, M dan Rahmat, N. 2018. Peningkatan Profesionalisme Guru Melalui Inovasi Pembelajaran. Jurnal Iqra': Kajian Ilmu Pendidikan, 3(2)

Mulyasa, E. 2009. Menjadi Kepala Sekolah Profesional. Bandung: PT. Remaja Rosdakarya

Muslim, B; Harapan, E dan Kesumawati, N. 2020. Kepemimpinan Kepala Sekolah Dalam Meningkatkan Mutu Pendidikan di SMA Negeri 1 Indralaya Selatan. Jurnal Intelektualita, Keislaman, Sosial dan Sains, 9(1)

Soekanto, S. 2007. Sosiologi Suatu Pengantar. Jakarta : PT Raja Grafindo Persada

Sugiyono. 2019. Metode Penelitian Kuantitatif Kualitatif. Bandung: Alfabeta.

Wahjosumidjo. 2013. Kepemimpinan Kepala Sekolah. Jakarta: PT. Raja Grafindo Persada

Yahya, Y. 2006. Pengantar Manajemen. Yogyakarta: Graha Ilmu 